cultural, scientific or educational problems of the countries in South-East Asia or the South-West Pacific. Such projects should accord with the aims of SEATO. Applicants for the fellowships must be nationals of SEATO countries: Australia, France, New Zealand, Pakistan, the Philippines, Thailand, Britain and the United States. Grants are normally for a period of from four to ten months and will include a monthly allowance of 400 dollars as well as tourist-class return air travel to the country or countrios where the research is undertaken. For British nationals full information and application forms can be obtained from the British Council, Universities Department, 65 Davies Street, London, W.1. The closing date for receipt of applications is February 5, 1966.

\section{International Esperanto Congress}

THE fiftieth International Esperanto Congress was held in Tokyo during August 1-8, 1965, under the patronage of Prof. Yuji Shibata, president of the Japanese Academy. This was the first such congress to take place in Asia. About 1,700 participants attended, from forty countries; all proceedings, formal and informal, were in Esperanto. Scientific lectures included four by Japanese scientists: F. Egami (molecular biology), M. Suzuki (electricity and life), S. Kawamura (soy-bean products) and N. Oka (a film on orang-utan intelligence); and two by foreigners: C. Støp-Bowitz (survival through glacial epochs), and R. A. Lewin (algae). Among topics discussed at a meeting of the International Science Association of Esperantists were norms for standardization of editorial policy and format for publication, and translation by computer (chief contributor, H. D. Neumann). Members of the Universal Medical Esperanto Association visited the National Cancer Institute and the Cardiac Surgery Hospital; they were also treated to a social reception at Chinzan-So, as guests of Dr. M. Shinoda. There were various post-congress excursions in and around Kyoto during August 8-13. The fifty-first International Esperanto Congress is scheduled for August 1966, in Budapest.

\section{Prof. J. B. S. Haldane}

Science Reporter, published by the Council of Scientific and Industrial Research, New Delhi, has published a "Haldane Number" (2, No. I1; November 1965. 50 p.). This is devoted entirely to assessments of the late Prof. J. B. S. Haldane by numerous European and Indian scientists. As might be expected, it deals more fully with the Indian period of his life, but other aspects are not neglected.

\section{Announcements}

Mr. E. B. Teesdale has been appointed director of the Association of the British Pharmaceutical Industry as from December 1 .

DR. A. R. Collies has been appointed director of the Civil Engineering Research Association as from January 1, following the resignation of Dr. M. F. Kaplan, who has been appointed professor of civil engineering at the University of Cape Town.

Dr. B. R. NiJhawan, director of the National Metallurgical Laboratory, India, has been awarded the 1964 Shanti Swarup Bhatnagar Memorial Award for his contributions in the field of engineering sciences by the governing body of the Indian Council of Scientific and Industrial Research.

Dr. F. Aylward has been appointed director and Dr. T. G. Gillespy deputy director of the Fruit and Vegetable Canning and Quick Freezing Research Association.

The seventh international Transplantation Conference, sponsored by the New York Academy of Sciences, will be held in New York City during February 14-16. Further information can be obtained from Felix T. Rapaport, New York University Medical Center, 560 First Avenue, New York 16, N.Y.

A seminar on "The Role of a Ministry of Technology", arranged by the Science of Science Foundation, will be held at the Ciba Foundation, London, on February 21. Further information can be obtained from the Science of Science Foundation, c/o the Ciba Foundation, 41 Portland Place, London, W.1.

A mesting of the Midlands Section of the Society for Analytical Chemistry will be held in the University of Birmingham on January 5. During the meeting the Elwell Award will be presented. Further information can be obtained from the Society for Analytical Chemistry, 14 Belgrave Square, London, S.W.1.

CoRrigendum. In the article entitled "Transpiration as related to Internal Water Content", by Dr. E. R. C. Reynolds, which appeared on p. 1001 of the August 28, 1965, issue of Nature, the quantities of water, where expressed as equivalent depths of water, are $6 \cdot 1$ times too large.

Erratum. In the article entitled "Relationships between Constituents of Cones and Male Flowers of the Hop (Humulus lupulus, L.)", by Dr. R. D. Hartley and Dr. R. A. Neve, which appeared on p. 804 of the November 20,1965, issue of Nature, the seventh word on the second line should read 'brewing', not 'breeding'.

\title{
THE NIGHT SKY IN JANUARY
}

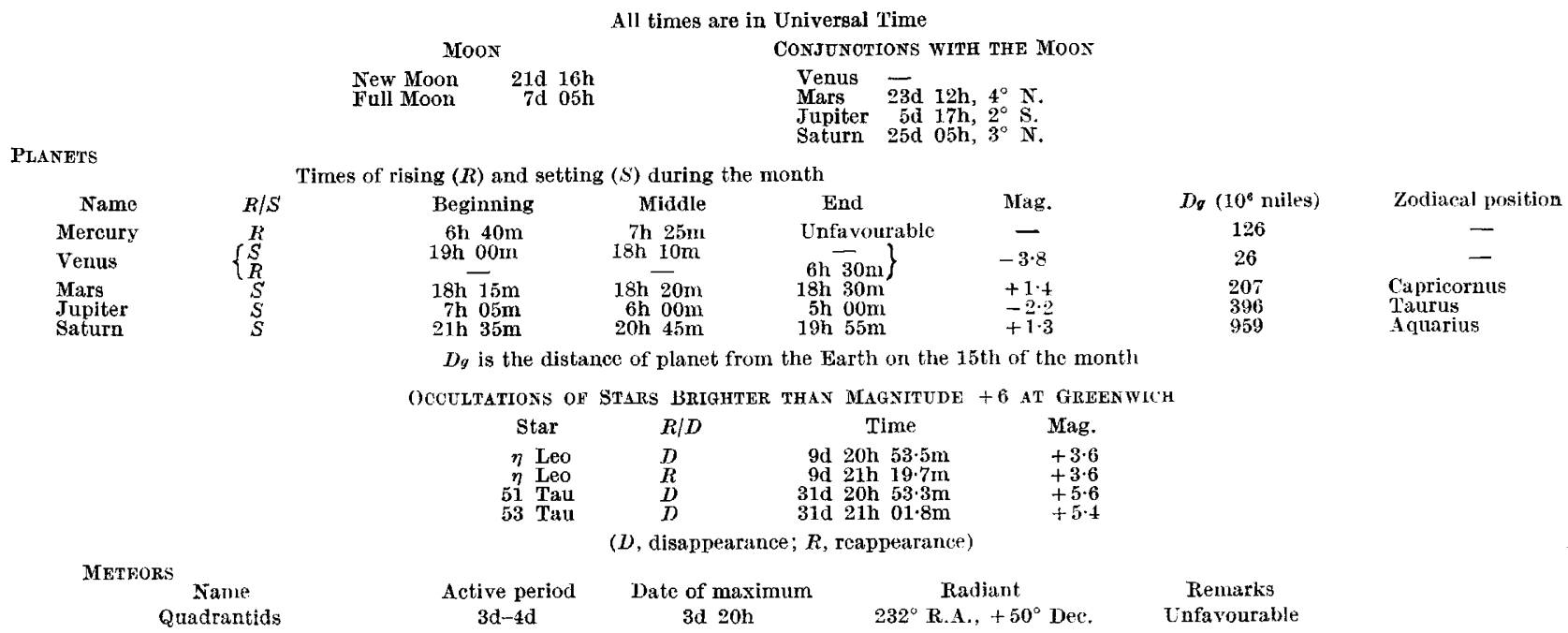

Other Phenomena: $8 \mathrm{~d}$ 05h, Venus $4^{\circ} \mathrm{N}$. of Mars 